\title{
Effect of Cutting Interval on Yield, Nutrient Composition and Digestibility Several Species of Mulberry
}

\author{
Hutasoit R, Ginting SP, Sirait J, Tarigan A \\ Indonesian Goat Research Station, PO Box 1, Sei Putih 20585, North Sumatra, Indonesia \\ h.rijanto@yahoo.com
}

\begin{abstract}
ABSTRAK
The high cost of feedstuffs is the problem in the development of ruminants, therefore finding new species is one of the strategies to increase the availability of feed. Mulberry (Morus spp.) is one of potential diversity of forage that can be used as animal feed. The aim of the study was to determine the effects of cutting interval on biomass yield, chemical composition and digestibility several species of mulberry as animal feed. In a factorial randomized block design, four species of mulberry was divided into 48 equal plots and subjected to three cutting intervals of 30, 60 and 90 days, each with four replications. The number of branches and the leaf:stem ratio was significant $(\mathrm{P}<0.05)$ on 30 days, Dry matter yield higher significant on 60 days, chemichal composition on DM was higher $(\mathrm{P}<0.05)$ of 41.53 on species M. nigra, influence on 60 days defoliation. The content of $\mathrm{OM}$ was highest on 30 days defoliation and not significanly different each species (averages 90.28\%). The higher frequency of defoliation cause the lower of $\mathrm{CP}$ content in mulberry. NDF on the M. cathayana has the lower fiber fraction among the three other species. $\mathrm{ADF}$ do not indicate the significance of each defoliation and species of mulberry treatment. These data suggest that species $M$. cathayana conducted on 30 and 60 days cutting interval could be potential feed source for livestock ruminants.
\end{abstract}

Key words: Cutting Interval, mulberry (Morus spp.), Nutrien Composition, Yield, Digestibility

\section{INTRODUCTION}

One of the major constraints to ruminant livestock production in developing countries is the scarcity, high cost and fluctuating quantity and quality of feedstuffs, especially during the dry season (Tuwei et al. 2003; Van et al. 2005). With the ever increasing human population and their high demand for animal protein, strategies for improving household food security and incomes in developing countries will heavily depend on better utilisation of unconventional ruminant feed resources. This demands better management regimes of already known unconventional feed resources, as well as the new and lesser known forage species capable of diversifying the supply of energy and protein required by ruminants (Danesh \& Stern 2005).

Mulberry plant (Morus spp.) is one of diversity of forage, commonly leaves were used as feed silkworms species Bombyx mori, useful to increase textile production in Indonesia. Mulberry is very potential that can be used as animal feed (Nguyen \& Le 2003; Bamikole et al. 2005; Miller et al. 2005; Yogesh 2013), crude protein content is quite high, ranging between 21-26\% with a level of digestibility between $75-85 \%$ (Saddul et al. 2003; Yulistiani 2008; Kandylis et al. 2009). There are 68 species of the genus Morus spread across Asia.The most common species used are $M$. alba (white mulberry), M. nigra (black mulberry), M. multicaulis, M. cathayana, M. rubra (red mulberry) and $M$. indica. Each mulberry variety requires different management to obtain optimum production needs adjustment varieties and how to grow the earning for a specific environment in obtaining the desired level of results. Methods of cultivation of mulberry plants to increase the productivity of silkworm has been much gained (Pudjiono \& Sandy 2008; Rahmayanti \& Sunarto 2008; Hartati \& Umar 2012; Nuraeni \& Beta 2012; Kumaidi \& Ekastuti 2013; 
Muin et al. 2015). But as livestock feed information obtained is still very low, so this method of cultivation of mulberry as animal feed should be considered to improve the production and quality of mulberry plants, management information defoliation concerning the cutting interval are important to increase optimal production and nutritional quality when used as a feed source.

In previous research has been conducted study variations in the growth of several species of Mulberry (Morus sp.) agains to the size of stem cuttings. The results of these study indicate that the size of the diameter stem cuttings $2 \mathrm{~cm}$ in species Cathayana has the highest growth (Hutasoit et al. 2013). Furthermore research on the effect of plant spacing and the first age defoliation after planting, which showed that the spacing of $1 \times 0.5$ $\mathrm{m}$ with cutting age 270 days after planting is the best treatment to obtain optimal productivity (Hutasoit et al. 2015). But these factors are not sufficient to determine the growth and optimal nutritional value as animal feed mulberry plants. So it is necessary to continue the study until the age of interval defoliation.

According Saddul et al. (2004), cutting early (5 weeks) will increase the crude protein content in the leaves and stems (24.9\%), but decreased in biomass production and content of the cell wall. Meanwhile, according to Boschini (2002) longer cutting makes crop production increased, but also increased cell wall content and crude protein content decreased, so the quality as animal feed would be reduced. Therefore, information regarding the interval of defoliation management is important in managing mulberry as forage to produce production and quality optimal nutrition. Thus interval defoliation need to be tested in the right age to acquire production data and a high level of nutrient content at the time of defoliation. The aim of the study was to determine the effects of cutting interval on biomass yield, chemical composition and digestibility several species of mulberry as animal feed.

\section{MATERIAL AND METHODS}

The research was done in the field experiment forage and laboratory of Indonesian goat research station, North Sumatera. The located at an altitude of $\pm 50 \mathrm{~m}$ from sea level, the type of soil podsolid (red sand), $\mathrm{pH}(4,5-4,7)$ soil with low $\mathrm{P}$ total $(7,06 \mathrm{mg} / 100 \mathrm{~g}), \mathrm{P}$ available $(5,94 \mathrm{ppm})$ and $\mathrm{Ca}(0.89 \%)$. Total annual rainfall was about $1800-2000 \mathrm{~mm} /$ year. This condition indicates that the rainfall is good enough. Four species of mulberry used in this study were 1 year old of Morus indica cv Kanva, Morus nigra, Morus multicaulis, and Morus cathayana, which were planted in the area of $1100 \mathrm{~m}^{2}$.

This activity begins with the trimming plants cutting height of 1 meter above the ground. Then the plants were designed in the plots trial which was divided into 48 plots to accommodate 3 treatments cutting interval, namely: 30, 60, and 90 days and consisted of 4 replicates. Area used was 1 plot with $3 \times 3 \mathrm{~m}$, and planting distance $1 \times 0,5 \mathrm{~m}$. There were 28 plants/plot, therefore the total amount plants in this research were 1344. Fertilizing were 15 tonnes/ha compost and 5 tonnes/ha lime, with chemical fertilizers $300 \mathrm{~kg} \mathrm{~N} / \mathrm{ha}, 200 \mathrm{~kg}$ $\mathrm{KCl} / \mathrm{ha}$ and $100 \mathrm{~kg} \mathrm{TSP} / \mathrm{ha}$ were given on all plants with the same treatments. Weeding was done manually once in a month, pests and diseases control have done until the plants can be harvested.

The number of branches and leaf:steam ratio were calculated before each harvesting time and average after ending the experiment. To calculate the leaf:stem ratio, the material obtained $500 \mathrm{~g}$ from each plot was separated each harvesting time into two fractions leaf and stem, then weighed.

The regrowths plants from each plant were harvested with cutting interval 30 days (12 times/year), 60 days (6 times/year), and 90 days (4 times/year), The total fresh matter from 
each plot was weighed, and registered to estimate fresh weight yield. The data for each harvesting time were collected and total in one year. $300 \mathrm{~g}$ samples was taken each treatments and replications and kept at room temperature for further analysis. After ending the experiment all samples were mixed according to treatments and replications as a material to determine the chemical content and the level of digestibility, $500 \mathrm{~g}$ were chopped into short length $\left(3\right.$ to $5 \mathrm{~cm}$ ) and dried in air-forced oven at $65^{\circ} \mathrm{C}$ for $48 \mathrm{~h}$ for dry matter (DM) determination. Fresh yield was converted to DM yield plot $^{-1}$ ha $^{-1}$ according to the equation: DM yield plot $^{-1}=$ Weight of fresh material $\times \mathrm{DM}(\%)$. DM yield were taken from each sub plot at every cutting time and same samples were preserved for chemical analysis. Samples were milled using a grinder (hummer mill) with a filter diameter of 1.0 $\mathrm{mm}$. N contents (with Kjeldahl method), organic matter and ash were analyzed according to AOAC (2005). Neutral detergent fiber (NDF) and acid detergent fiber (ADF) were analyzed according to the method of Van Soest \& Robertson (1985). In vitro digestibility such as dry matter, nitrogen content, and organic matter (OM) performed according to the method Tilley \& Terry (1963). $1.5 \mathrm{~g}$ samples of each treatment inserted into fermenter tube then added a solution of artificial saliva of $18.0 \mathrm{ml}(\mathrm{pH} 6.5$ to 6.9), and then inoculated with rumen fluid as much as $12.0 \mathrm{ml}$. Each media in vitro added with gas $\mathrm{CO}_{2}$ for \pm 30 seconds in anaerobic conditions, tube inserted into a shaker water bath and incubated 48 hours, and then added $0.2 \mathrm{ml}$ of saturated $\mathrm{HgCl}_{2}$ (2-3 drops). Furthermore, the tube centrifuged at $5000 \mathrm{rpm}$ for 20 minutes. Sediment in a fermenter tube dissolved with $30 \mathrm{ml}$ of $\mathrm{HCl}$-pepsin $(0.2 \%)$ and incubated for 48 hours at a temperature of $39-40^{\circ} \mathrm{C}$. Furthermore, the solution is filtered and then dried in an oven at $105^{\circ} \mathrm{C}$ for 24 hours, and then weighed to determine dry matter digestibility. Then the samples were dried in an electric furnace at a temperature of $600^{\circ} \mathrm{C}$ for 24 hours, and then weighed to determine the organic matter digestibility. The Nitrogen digestibility were analyzed by Kjeldahl method.

The study was conducted in a factorial randomized block design, consisting of 2 factors. The first factor were species of mulberry (Morus indica cv Kanva, Morus nigra, Morus cathayana, and Morus multicaulis). The second factor were cutting interval (30, 60, and 90 days), consists of 4 replication. Data was analyzed using ANOVA method, and if there was a significant difference $(\mathrm{P}<0.05)$ followed by Duncan's multiple range test, (DMRT).

\section{RESULTS AND DISCUSSION}

\section{The number of branches}

In this study there was not found interaction between species and cutting interval. The average number of branches were not different among species of mulberry. The present results show that amount of branches decreased on the high frequency of defoliation, due to enlargement of the primary branches, their energy competition between branches cause the small branches are not growing. According to Nasrin et al. (2014), this is most likely due to the sturdy branches grow larger and become the primary stem, while small branches will decrease as oppressed by the strong branches. So that the cutting interval of 90 days the number of branches that can be harvested is reduced, which had an average number of branches in 30 days amounted 48.81, but at cutting intervals the average of 60 and 90 days later reduced to 29.24 and $31.88 \%$, respectively. 
Table 1. The number of branches of different cutting interval at several spesies of mulberry

\begin{tabular}{lcccc}
\hline \hline \multirow{2}{*}{ Species } & \multicolumn{3}{c}{ Cutting interval (days) } & \multirow{2}{*}{ Average } \\
\cline { 2 - 4 } & 30 & 60 & 90 & \\
\hline M. indica cv Kanva & $42.62 \pm 13.39$ & $37.24 \pm 3.58$ & $36.83 \pm 1.26$ & $38.90 \pm 7.50^{\mathrm{a}}$ \\
M. nigra & $51.45 \pm 8.17$ & $30.87 \pm 8.31$ & $34.33 \pm 0.76$ & $38.88 \pm 11.19^{\mathrm{a}}$ \\
M. multicaulis & $54.39 \pm 5.94$ & $35.79 \pm 3.58$ & $34.33 \pm 1.04$ & $41.51 \pm 10.30^{\mathrm{a}}$ \\
M. cathayana & $46.79 \pm 5.18$ & $34.24 \pm 2.54$ & $27.50 \pm 3.00$ & $36.18 \pm 9.11^{\mathrm{a}}$ \\
\hline Average & $48.81 \pm 8.85^{\mathrm{a}}$ & $34.54 \pm 4.95^{\mathrm{b}}$ & $33.25 \pm 3.92^{\mathrm{b}}$ & \\
\hline
\end{tabular}

Different superscripts in a column or same row indicate significant differences $(\mathrm{P}<0.05)$

\section{Leaf : stem ratio}

The leaf : stem ratio of mulberry expressed on cutting interval is presented in Figure 1. There was interaction leaf:steam on the species and cutting interval. The highest obtained on $M$. nigra (1.71) at the age of 30 days defoliation, but dropped dramatically at the 90 days (0.68). While the species M. multicaulis and $M$. indica cv Kanva were 1.60 and 1.45 respectively at the age of cut 30 days. However, there was a change on the 60 days defoliation, the ratio of the $M$. multicaulis was lower than $M$. indica cv Kanva 1.10 and 1.26 respectively and the age of 90 days cutting interval $M$. indica $\mathrm{cv}$ Kanva obtain the highest ratio compared to three other species (0.93). It was because increasing of the age plant also increasing number fallen leaves.

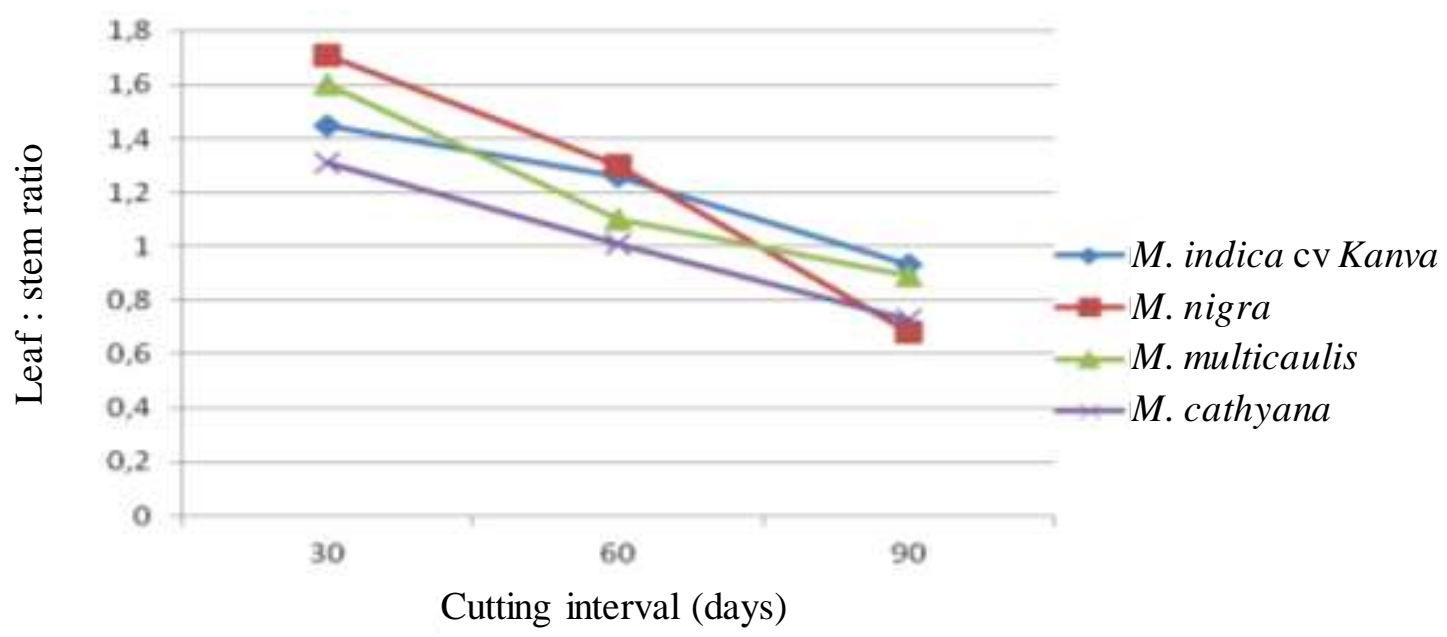

Figure 1. Leaf : stem ratio of different cutting interval at several spesies of mulberry

From the data obtained appears that the highest ratio of leaf/stem produced at 30 days cutting interval whereas the lowest was recorded from 90 days cutting intervals both in $M$. nigra. The average of leaf : steam ratio (1.16) ranged from 0.68 to 1.71 . The decline of leaf : stem ratio in conjunction with the increasing age of cuts. Leaf/stem obtained in the present study were higher than reported by Ginting et al. (2013), (0,73). On the other hand, Kabi \& Bareeba (2008) who showed that Morus alba on different cutting frequencies 1 and 2 month were higher than this research, leaf:stem ratio 3.3, 2.3, respectively. The ratio of leaves/stems of plants is important to know because it affects the amount of consumption and nutrient content, generally the amount of consumption and nutrient content obtained at higher than the leaves on the stem. Decrease of ratio leaf in accordance with those reported by Bonesmo \& Bélanger (2002) and Herdiawan \& Sutedi (2012) who 
stated that the increase in age of plant followed by an increase in the proportion of branches as well as the content of the cell walls (fibers) (Djuned et al. 2005). So that from the aspect of its agronomic, the frequency of 30 days is an optimal defoliation management in the utilization of mulberry as forage plants because the leaves possess a fraction higher.

\section{Dry matter yield}

The effect of cutting interval on dry matter yield is shown in Table 2. The data showed that the treatment of species mulberry and cutting interval there was interaction. The dry matter yield $\left(\mathrm{t} \mathrm{ha}^{-1} \mathrm{y}^{-1}\right)$ ranges 5,81-16.66 was not significant $(\mathrm{P}>0.05)$ among species of mulberry from the cutting frequencies 30 to 60 days, but on 90 days were different between $M$. cathayana and $M$. indica cv Kanva and M. nigra and M. multicaulis. The effect of cutting interval was increasing significantly $(\mathrm{P}<0.05)$ on 60 days, but the production declined in cutting frequency of 90 days on species $M$. nigra and $M$. multicaulis (5.90 and 6.12 respectively).

Table 2. Total dry matter yield (ton ha $^{-1} \mathrm{year}^{-1}$ ) of different cutting interval at several spesies of mulberry

\begin{tabular}{lccc}
\hline \hline \multirow{2}{*}{ Species } & 30 & 60 & \multicolumn{3}{c}{ Cutting interval (days) } \\
\cline { 2 - 4 } & $9.62 \pm 3.85^{\mathrm{ab}}$ & $16.66 \pm 9.33^{\mathrm{a}}$ & $13.93 \pm 7.92^{\mathrm{a}}$ \\
\hline M. indica cv Kanva & $6.70 \pm 2.38^{\mathrm{b}}$ & $10.65 \pm 7.94^{\mathrm{a}}$ & $5.90 \pm 4.74^{\mathrm{b}}$ \\
M. nigra & $5.81 \pm 1.40^{\mathrm{b}}$ & $10.68 \pm 8.20^{\mathrm{a}}$ & $6.12 \pm 4.79^{\mathrm{b}}$ \\
M. multicaulis & $6.93 \pm 2.33^{\mathrm{b}}$ & $15.27 \pm 4.70^{\mathrm{a}}$ & $13.38 \pm 3.17^{\mathrm{a}}$ \\
\hline M. cathayana &
\end{tabular}

Different superscripts in a column or same row indicate significant differences $(\mathrm{P}<0.05)$

Although the number of cutting times in frequency of 30 days (12 times a year) is higher than frequency of 60 days (6 times in a year), but the DM yield is fewer. It is due to biomass produced on frequency 30 days was too young and much water. At the defoliation 90 days decreased production, although the dry matter content is highest on the cutting interval of 90 days (chemical composition in Tabel 3), but amount of defoliation can only do as much as four times in one year. According to this study can be recommended that the cutting interval of 60 days is the best limit to do as animal feed. Further demonstrate the potential role of mulberry in supplying high production for dairy cattle when harvested at a frequency of 60 days (Yao et al. 2000). Dry matter yield on cutting interval 60 days in this study ranged 10.65-16.66 t ha-1 $\mathrm{y}^{-1}$, it is similar with reported by Bamikole et al. (2005), that cutting interval of 60 days on mulberry plants produce 12-15 $\mathrm{t} \mathrm{ha}^{-1} \mathrm{y}^{-1}$. Frequency of defoliation can affect dry matter production (Almaida \& Fonseca 2002). The dry matter yield of the mulberry in this study were similar with the values reported by Mei et al. (2013); Hutasoit et al. (2015), that the long age causing the plant to have more opportunities make the process of photosynthesis, enabling the plant increases production of the canopy so that dry matter yield can increase to a certain extent.

\section{Chemical composition}

Composition DM ranged 28.07-41.53\% influenced $(\mathrm{P}<0.05)$ by species and cutting interval. The highest content in species $M$. nigra on cutting interval 60 days. The DM content of mulberry obtained in the current study was higher than that reported by $\mathrm{Vu}$ et al. 
(2011) who reported that DM content mulberry was 19.0\%. and lower than that reported by Inan (2012), 42.20\% in M. nigra. The content of DM was higher in the treatment of cutting interval of 60 and 90 days, but lower and have significant effect $(\mathrm{P}<0.05)$ on the frequency of 30 days. According Kabi \& Bareeba (2007); Mei et al. (2013); Nasrin et al. (2014), DM levels increase with cutting age treatment due to thickening of the cell wall in plants.

Table 3. Chemical composition of different cutting interval at several spesies of mulberry

\begin{tabular}{|c|c|c|c|c|}
\hline \multirow{2}{*}{ Variables } & \multirow{2}{*}{ Species } & \multicolumn{3}{|c|}{ Cutting interval (days) } \\
\hline & & 30 & 60 & 90 \\
\hline \multirow[t]{4}{*}{$\mathrm{DM}(\%)$} & M. indica cv Kanva & $34.51 \pm 0.49^{\mathrm{b}}$ & $31.64 \pm 1.08^{b}$ & $39.77 \pm 0.18^{\mathrm{a}}$ \\
\hline & M. nigra & $30.90 \pm 1.09^{c}$ & $41.53 \pm 1.96^{\mathrm{a}}$ & $34.81 \pm 1.89^{b}$ \\
\hline & M. multicaulis & $28.07 \pm 1.06^{\mathrm{b}}$ & $38.78 \pm 1.34^{\mathrm{a}}$ & $38.32 \pm 0.46^{\mathrm{a}}$ \\
\hline & M. cathayana & $31.69 \pm 2.29^{b}$ & $34.18 \pm 0.31^{\mathrm{a}}$ & $35.00 \pm 1.91^{\mathrm{a}}$ \\
\hline \multirow[t]{4}{*}{ Ash (\%) } & M. indica cv Kanva & $10.04 \pm 0.76^{\mathrm{a}}$ & $9.63 \pm 0.28^{b}$ & $9.89 \pm 0.87^{b}$ \\
\hline & M. nigra & $9.49 \pm 0.15^{\mathrm{b}}$ & $8.66 \pm 0.36^{\mathrm{b}}$ & $10.33 \pm 0.14^{\mathrm{a}}$ \\
\hline & M. multicaulis & $10.45 \pm 0.69^{\mathrm{a}}$ & $10.09 \pm 0.99^{\mathrm{a}}$ & $12.10 \pm 0.03^{\mathrm{a}}$ \\
\hline & M. cathayana & $9.53 \pm 0.19^{b}$ & $9.47 \pm 0.74^{\mathrm{b}}$ & $10.61 \pm 1.12^{\mathrm{a}}$ \\
\hline \multirow[t]{4}{*}{$\mathrm{OM}(\%)$} & M. indica cv Kanva & $89.96 \pm 2.22^{\mathrm{a}}$ & $90.37 \pm 1.65^{\mathrm{a}}$ & $90.57 \pm 1.56^{\mathrm{a}}$ \\
\hline & M. nigra & $90.79 \pm 2.02^{\mathrm{a}}$ & $89.81 \pm 2.43^{\mathrm{a}}$ & $89.18 \pm 2.67^{\mathrm{a}}$ \\
\hline & M. multicaulis & $89.91 \pm 1.45^{\mathrm{a}}$ & $87.93 \pm 1.89^{b}$ & $87.87 \pm 1.88^{\mathrm{b}}$ \\
\hline & M. cathayana & $90.47 \pm 1.02^{\mathrm{a}}$ & $90.53 \pm 1.31^{\mathrm{a}}$ & $89.70 \pm 1.41^{\mathrm{a}}$ \\
\hline \multirow[t]{4}{*}{$\mathrm{CP}(\%)$} & M. indica cv Kanva & $27.68 \pm 2.66^{\mathrm{a}}$ & $24.06 \pm 1.00^{\mathrm{b}}$ & $23.87 \pm 0.94^{b}$ \\
\hline & M. nigra & $27.75 \pm 0.19^{\mathrm{a}}$ & $25.06 \pm 0.06^{\mathrm{b}}$ & $25.93 \pm 0.69^{b}$ \\
\hline & M. multicaulis & $26.37 \pm 1.94^{\mathrm{a}}$ & $23.31 \pm 6.19^{b}$ & $24.56 \pm 0.50^{b}$ \\
\hline & M. cathayana & $28.12 \pm 0.88^{\mathrm{a}}$ & $26.06 \pm 1.81^{\mathrm{b}}$ & $25.31 \pm 0.50^{b}$ \\
\hline \multirow[t]{4}{*}{$\operatorname{NDF}(\%)$} & M. indica cv Kanva & $35.85 \pm 0.67^{\mathrm{a}}$ & $34.63 \pm 1.16^{\mathrm{a}}$ & $37.41 \pm 1.77^{\mathrm{b}}$ \\
\hline & M. nigra & $33.51 \pm 0.30^{\mathrm{a}}$ & $34.22 \pm 1.41^{\mathrm{a}}$ & $33.60 \pm 0.81^{\mathrm{a}}$ \\
\hline & M. multicaulis & $33.62 \pm 1.02^{\mathrm{a}}$ & $32.51 \pm 0.64^{\mathrm{a}}$ & $33.33 \pm 0.30^{b}$ \\
\hline & M. cathayana & $29.31 \pm 1.01^{\mathrm{b}}$ & $29.54 \pm 1.38^{b}$ & $30.66 \pm 0.92^{b}$ \\
\hline \multirow[t]{4}{*}{$\operatorname{ADF}(\%)$} & M. indica cv Kanva & $34.51 \pm 2.83^{\mathrm{a}}$ & $34.32 \pm 2.19^{\mathrm{a}}$ & $34.16 \pm 3.62^{\mathrm{a}}$ \\
\hline & M. nigra & $32.16 \pm 1.32^{\mathrm{a}}$ & $32.12 \pm 1.81^{\mathrm{a}}$ & $34.13 \pm 2.17^{\mathrm{a}}$ \\
\hline & M. multicaulis & $28.20 \pm 1.18^{\mathrm{a}}$ & $30.21 \pm 1.19^{\mathrm{a}}$ & $31.01 \pm 1.18^{\mathrm{a}}$ \\
\hline & M. cathayana & $30.12 \pm 3.82^{\mathrm{a}}$ & $28.30 \pm 3.16^{\mathrm{a}}$ & $28.45 \pm 4.46^{\mathrm{a}}$ \\
\hline
\end{tabular}

Different superscripts indicate significant differences $(\mathrm{P}<0.05)$

The highest ash content obtain on the species M. multicaulis $(12.10 \%)$ on cutting interval of 90 days. While the lower content obtain on M. Nigra was significantly different to the frequency of 30 and 60 respectively. The ash content in this study is higher than the results obtained Linghong et al. (2012) of 3.64-6.75\%. While Shahid et al. (2012) reported the ash content was higher (11.73\%).

The content of OM was not significantly different each species (averages 90.28\%). The result decrease on 60 and 90 days defoliation only on species M. multicaulis (87.93$87.87 \%$, respectively). The result is lower to that reported by $\mathrm{Vu}$ et al. (2011) amounted to $86.4 \%$. 
The content of $\mathrm{CP}$ of various cutting age in this study showed that the higher frequency of defoliation cause the lower of CP content in mulberry. Not significant each species. In this study has been quite effective cutting as animal feed and significantly different $(\mathrm{P}<0.05)$ compared with both cutting age of 60 and 90 days. The content of CP in this study is higher compared with previous study reported by Sanchez (2000), Saddul et al. (2003), Nguyen \& Le (2003), Vu et al. (2011) and Bamikole et al. (2005), obtaining the content of CP on mulberry plants: 15 to $28,24.90,22.2$ to $24.30,22$, and $23.20 \%$, respectively.

The result obtained that in the treatment of species indicate the significance of NDF content was lower on M. cathayana. The higher result were reported by Jefferson (2005), which contains $33.99 \% \mathrm{NDF}$. In the parameter of $\mathrm{ADF}$ do not indicate the significance of each defoliation and species of mulberry treatment.

\section{Mulberry digestibility value}

Table 4. Digestibility of different cutting interval at several spesies of mulberry

\begin{tabular}{llcccc}
\hline \hline \multirow{2}{*}{ Variables } & \multicolumn{1}{c}{ Species } & \multicolumn{3}{c}{ Cutting interval (days) } & \multirow{2}{*}{ Average } \\
\cline { 3 - 5 } & M. indica cv Kanva & $82.61 \pm 0.78$ & $81.72 \pm 0.83$ & $81.37 \pm 1.38$ & $81.90 \pm 1.05^{\mathrm{a}}$ \\
\hline DM (\%) & M. nigra & $80.73 \pm 0.97$ & $78.59 \pm 0.99$ & $79.32 \pm 0.05$ & $79.55 \pm 1.17^{\mathrm{b}}$ \\
& M. multicaulis & $79.83 \pm 0.70$ & $78.71 \pm 1.0$ & $78.45 \pm 1.39$ & $79.00 \pm 1.12^{\mathrm{b}}$ \\
& M. cathayana & $80.43 \pm 1.09$ & $82.16 \pm 1.0$ & $80.15 \pm 1.64$ & $80.91 \pm 1.45^{\mathrm{a}}$ \\
& Average & $80.90 \pm 1.33^{\mathrm{a}}$ & $80.30 \pm 1.9^{\mathrm{ab}}$ & $79.82 \pm 1.57^{\mathrm{b}}$ & \\
\hline OM (\%) & M. indica cv Kanva & $82.83 \pm 0.47$ & $81.70 \pm 0.99$ & $79.86 \pm 1.99$ & $81.46 \pm 1.72^{\mathrm{a}}$ \\
& M. nigra & $80.81 \pm 0.70$ & $78.45 \pm 1.0$ & $79.33 \pm 0.03$ & $79.53 \pm 1.20^{\mathrm{cb}}$ \\
& M. multicaulis & $79.81 \pm 0.39$ & $78.23 \pm 1.90$ & $77.88 \pm 1.22$ & $78.69 \pm 1.45^{\mathrm{c}}$ \\
& M. cathayana & $80.09 \pm 1.29$ & $81.78 \pm 0.96$ & $78.29 \pm 0.85$ & $80.05 \pm 1.76^{\mathrm{b}}$ \\
& Average & $80.88 \pm 1.41^{\mathrm{a}}$ & $80.04 \pm 2.09^{\mathrm{a}}$ & $78.84 \pm 1.34^{\mathrm{b}}$ & \\
\hline CP (\%) & M. indica cv Kanva & $80.95 \pm 3.77$ & $71.43 \pm 1.02$ & $77.96 \pm 6.54$ & $76.78 \pm 5.68^{\mathrm{d}}$ \\
& M. nigra & $86.57 \pm 0.67$ & $81.61 \pm 1.01$ & $82.79 \pm 2.13$ & $82.32 \pm 1.34^{\mathrm{b}}$ \\
& M. multicaulis & $81.41 \pm 4.41$ & $75.81 \pm 0.10$ & $81.31 \pm 0.29$ & $79.51 \pm 3.55^{\mathrm{c}}$ \\
& M. cathayana & $86.40 \pm 1.77$ & $88.02 \pm 0.31$ & $80.78 \pm 1.38$ & $85.06 \pm 1.51^{\mathrm{a}}$ \\
& Average & $82.83 \pm 3.34^{\mathrm{a}}$ & $81.22 \pm 6.54^{\mathrm{b}}$ & $80.71 \pm 4.20^{\mathrm{b}}$ & \\
\hline
\end{tabular}

Different superscripts in a column or same row indicate significant differences $(\mathrm{P}<0.05)$

Table 4 presents the in vitro digestibility of nutrients in the mulberry. The data show that the treatment of species mulberry and cutting interval there is no interaction affect $(\mathrm{P}>0.05)$ the $\mathrm{DM}, \mathrm{OM}$ and $\mathrm{CP}$ in vitro digestibility. The average of $\mathrm{DM}$ digestibility was higher than those reported by Gonzalez et al. (2008); Vu et al. (2011) of 66.4\% in the species M. alba. While Kandylis et al. (2009), reported was higher 89.8\%. OM digestibility was slightly higher on the cutting interval of 30 days with average $80.88 \%$ than defoliation of 60 and 90 days, ranging from 80.04 to $78.84 \%$ respectively. CP digestibility of several level cutting interval in this study are more varied ranging from 71.43 to $88.02 \%$. High levels of $\mathrm{CP}$ digestibility at cutting frequency of 30 days is the highest and similar with previous reports (Yulistiani 2008; Kandylis et al. 2009). Digestibility on cutting frequency of 60 and 90 days was significantly decreased be 81.22 
and $80.71 \%$, respectively. The low effective CP degradability defoliation 60 dan 90 days compared to 30 days in this study may be due to the high tannin levels reported earlier (Tuwei et al. 2003). The effective CP degradability with decreasing cutting frequency was also associated with decrease in leaf:steam ratio and increased lignification of the fibre at the expense of CP (Kabi \& Bareeba 2008). Therefore, management options that involve cutting mulberry regrowth at maturities of 30 days, when the leafstem ratio is greater than 1.0 , is crucial in making a decision when to harvest forage with high nutritional value.

\section{CONCLUSION}

The present results show that the number of branches and leaf : stem ratio increase significant on 30 days cutting interval and decreased on the high frequency of defoliation. While dry matter yield highest on 60 days, production declined in cutting frequency of 90 days. Chemichal composition on DM was highest of $41.53 \%$ (M. nigra) influenced on 60 days cutting interval. The highest ash content obtain on the species $M$. multicaulis (12.10\%), OM was highest on 30 days defoliation and not significanly different each species (averages 90.28\%). The higher frequency of defoliation cause the lower of CP content in mulberry. It is recommended on 30 days is indicative of a good protein source for ruminant livestock. Moreover, NDF content on the $M$. cathayana has the lower fiber fraction among the three other species. ADF do not indicate the significance on each defoliation and species of mulberry treatment. The present results on the yield, nutrient contents and digestibilty in mulberry suggest that it could be a suitable protein supplement for ruminant livestock. If grown in abundance, it can help small and medium scale farmers to overcome the shortages of quality feeds leading to a reduction in the livestock production cost.

\section{ACKNOWLEDGEMENT}

The authors would like to thank the head office of Indonesian Goat Research Station in North Sumatera for permission using the existing mulberry plot of the Institute to be used in this experiment.

\section{REFERENCES}

AOAC. 2005. Method of analysis. $18^{\text {th }}$ Ed. Washington DC (USA): Association of Official Analytical Chemists.

Bamikole MA, Ikhatua MI, Ikhatua UJ, Ezenwa. 2005. Nutritive value of Mulberry (Morus spp.) leaves in the growing rabbits in Nigeria. Pak J Nutr. 4:231-236.

Boschini CF. 2002. Nutritional quality of mulberry cultivated for ruminant feeding. In: MD Sanchez, ed. Mulberry for animal production, FAO animal production and health paper. Rome (Italy): FAO. p. 171-181.

Bonesmo H, Bélanger G. 2002. Timothy yield and nutritive value by the CATIMO Model: I. Growth and nitrogen. Agron J. 94:337-345.

Danesh MM, Stern MD. 2005. Ruminal and post-ruminal protein disappearance of various feeds originating from Iranian plant varieties determined by the in situ mobile bag technique and alternative methods. Anim Feed Sci Tech. 118:31-46.

De Almeida JE, Fonseca TC. 2002. Mulberry germplasm and cultivation in Brazil. In: MD Sanchez, ed. Mulberry for animal production. FAO animal production and health paper. Rome (Italy): FAO. p. 73-95. 
Djuned H, Mansyur, Heni BW. 2005. Pengaruh umur pemotongan terhadap kandungan fraksi serat hijauan murbei (Morus indica 1. var. Kanva-2). In: Mathius IW, Bahri S, Tarmudji, Prasetyo LH, Triwulanningsih E, Tiesnamurti B, Sendow I, Suhardono, editors. Inovasi teknologi peternakan untuk meningkatkan kesejahteraan masyarakat dalam mewujudkan kemandirian dan ketahanan pangan nasional. Prosiding Seminar Nasional Teknologi Peternakan dan Veteriner. Bogor, 12-13 September 2005. Bogor (Indonesia): Puslitbangnak. p. 859-854.

Ginting SP, Tarigan A, Hutasoit R, Yulistiani D. 2013. Karakteristik morfologi dan agronomik serta kualitas nutrisi beberapa spesies murbei. In: Purwantari ND, Saepulloh M, Iskandar S, Anggraeni A, Ginting SP, Priyanti A, Wiedosari E, Yulistiani D, Inounu I, Bahri S, Puastuti P, editors. Inovasi Teknologi Peternakan dan Veteriner Berbasis Sumber Daya Lokal yang Adaptif dan Mitigatif terhadap Perubahan Iklim. Prosiding Seminar Nasional Teknologi Peternakan dan Veteriner. Medan, 3-5 September 2013. Bogor (Indonesia): Puslitbangnak. p. 468-477.

González GE, Arece J, Archimède H, Gomarín PP, Cáceres O. 2008. Productive response of tropical lambs reared in two contrasting management systems after weaning and using woody forage species. Livest Res Rural Dev. 20. [Internet]. [cited 17 June 2015]. Avaliable from: www.lrrd.org/lrrd20/11/gonz20185.htm.

Hartati, Umar. 2012. Pengaruh pemberian jenis murbei Morus multicaulis dan Morus cathayana terhadap produksi kokon ulat sutera (Bombyx mori L.) varietas lokal, Jepang, China dan Rumania. J Sainsmat. 1:1-12.

Herdiawan I, Sutedi E. 2012. Produksi tanaman pakan Indigofera sp. pada tingkat cekaman kekeringan dan Interval pemangkasan yang berbeda. JITV. 17:161-167.

Hutasoit R, Simon G, Andi T. 2013. Pengaruh diameter stek batang terhadap pertumbuhan bibit pada empat spesies tanaman murbei (Morus sp). In: Purwantari ND, Saepulloh M, Iskandar S, Anggraeni A, Ginting SP, Priyanti A, Wiedosari E, Yulistiani D, Inounu I, Bahri S, Puastuti P, editors. Inovasi Teknologi Peternakan dan Veteriner Berbasis Sumber Daya Lokal yang Adaptif dan Mitigatif terhadap Perubahan Iklim. Prosiding Seminar Nasional Teknologi Peternakan dan Veteriner. Medan, 3-5 September 2013. Bogor (Indonesia): Puslitbangnak. p. 461-467.

Hutasoit R, Ginting S, Sirait J. 2015. Productivity and chemical composition of several mulberry species (Morus spp.) agains spacing plant, and cutting age. J Trop Vet Biomedical. 1:43-51.

Inan G. 2012. Effect of species on nutritive value of mulberry leaves. J Fac Vet Med Kafkas Univ. 15:865-869.

Jefferson PG. 2005. Leaf and stem nutritive value of timothy cultivars of different maturity at an irrigated site in South Western Saskatchewan. J Plant Sci. 85:377-383.

Kabi F, Bareeba FB. 2008. Herbage biomass production and nutritive value of mulberry (Morus alba) and Calliandra calothyrsus harvested at diffenert cutting frequenscies. Anim Feed Sci Tech. 140:178-190.

Kandylis K, Hadjigeorgiou I, Harizanis P. 2009. The nutritive value of mulberry leaves (Morus $a l b a$ ) as a feed supplement for sheep. J Trop Anim Health Prod. 41:17-24.

Kumaidi A, Ekastuti DA. 2013. Pertumbuhan dan produktivitas ulat sutera Bombyx mori 1. yang diberi pakan ayam broiler. Bogor (Indonesia): Acta Vet Indones. 1:1-7.

Linghong L, Xiangyang W, Maomao Z, Weiguo Z, Fang L, Ye Z, Liuqing Y. 2012. Chemical composition, nutritional value, and antioxidant activities of eight mulberry cultivars from China. J Pharm Mag. 31:215-224.

Mei VS, Herni S, Hermanto. 2013. Pengaruh umur pemotongan terhadap produktivitas gamal (Gliricidia sepium). J Ilmu-Ilmu Peternakan 2:25-35.

Miller D, Mcdonald D, Asiedu FH. 2005. The effect of mulberry leaf meal on the growth performance of weaner goats in Jamaica. CARDI Review 5:5-11. 
Muin N, Suryanto H, Minarningsih. 2015. Uji coba hibrid Morus khunpai dan M. indica sebagai pakan ulat sutera (Bombyx mory linn). J Penelitian Kehutanan Wallacea. 2:137-145.

Nasrin S, Abd Razak A, Khan SH, Awis QS, Halimatun Y, Jahangir H. 2014. The effect of cutting interval on yield and nutrient composition of different plant fractions of Moringa Oleifera tree. J Food Agric Env.12:599-604.

Nguyen XB, Le DN. 2003. Evaluation of some unconventional trees/plants as ruminant feeds in central Vietnam. In: Preston TR, Brian O, editors. Proceedings of Final National SeminarWorkshop on Sustainable Livestock Production on Local Feed Resources, HUAF-SAREC, Hue City, 25-28 March, 2003. [Internet]. [Retrieved on June 10, 2014]. Available from: http:/www.mekarn.org/sarec03/bahue.htm.

Nuraeni S, Beta P. 2012. Aspek biologis ulat sutera (Bombyx mori 1.) dari dua sumber bibit di Sulawesi Selatan. J Perennial. 4:10-17.

Pudjiono S, Sandy S. 2008. Marfologi tanaman hibrid murbei di Purwobinangun Yogyakarta. J Pemuliaan Tanaman Hutan. 21:5-7.

Rahmayanti S, Sunarto. 2008. Pengaruh pemberian limbah pemeliharaan ulat sutera terhadap produksi daun murbei. J Penelitian Hutan dan Konservasi Alam. 5:451-459.

Yao JB, Yan XQ, Wang, Lui JX. 2000. Nutritional evaluation of mulberry leaves as feeds for ruminants. Livest Res Rural Dev. 12:85-90.

Yogesh KW. 2013. Chemical and physicalanalysis of Morus Nigra (black mulberry) for its pulpability. J Adv Basic Sci. 1:40-44.

Yulistiani D. 2008. Hijauan murbei untuk supleymentasi protein pakan sapi perah. In: Diwyanto K, Wina E, Priyanti A, Natalia L, Herawati T, Purwandaya B, editors. Prosiding Prospek Industri Sapi Perah Menuju Perdagangan Bebas 2020. Jakarta, 21 April 2008. Bogor (Indonesia): Puslitbangnak dan STEKPI. p. 119-123.

Saddul D, Jelan ZA, Liang JB. and Halim RA. 2003. The production potentials of Morus alba as an Animal Feed: The Effect of Harvest Stage on Yield, Persistence and Nutritional Properties. Proceeding. 25th Malaysian Societies Animal Production. Conference. 1-3 August 2003. Kuala Lumpur (Malaysia): Malaysian Society of Animal Production. p. 39-52.

Saddul D, Jelan ZA, Liang JB. and Halim RA. 2004. The potential of mulberry (Morus alba): as a fodder crop: The effect of plant maturity on yield. Persistence and nutrient compositonof plant fractions. Asian-Aus. J Anim Sci. 17: 1657-1662.

Sanchez MD. 2000. Mulberry: an exceptional forages available almost worldwide. World Anim Rev. 93:1-21.

Shahid I, Umer Y, Sirajuddin, Kim WC, Raja AS, Kamal U. 2012. Proximate composition and ntioxidant potential of leaves from three varieties of mulberry (Morus sp.). Int $\mathrm{J}$ Mol Sci.13:6651-6664.

Tilley JMA, Terry RA. 1963. A two stage technique for in vitro digestion of forage crops. J Br Grassl Soc. 18:104-111.

Tuwei PK, Kang'ara JNN, Mueller HI, Poole J, Ngugi FK. 2003. Factors affecting biomass production and nutritive value of Calliandra calothyrsus leaf as fodder for ruminants. J Agric Sci. 14:113-127.

Van Soest PJ, Robertson JB. 1985. Analysis of Forages and Fibrous Foods: A laboratory manual for animal science 613. Ithaca (USA): Cornell University. p. 202.

Van DTT, Mui NT, Ledin I. 2005. Tropical foliages: effect of presentation method and species on intake by goats. Anim Feed Sci Technol. 118:1-17.

Vu CC, Verstegen MWA, Hendriks WH, Pham KC. 2011 The nutritive value of mulberry leaves (Morus alba) and partial replacement of cotton seed in rations on the performance of growing Vietnamese cattle. Asian Aust J Anim Sci. 9:1233-1242. 